\title{
Revisiting the Causes and Meaning of Higher Education Massification in Sub-Saharan Africa: Evidence from Cameroon
}

\author{
Jean Patrick Mve \\ College of Teacher Education, Zhejiang Normal University, Jinhua, China \\ Email:mve109@yahoo.fr
}

How to cite this paper: Mve, J. P. (2021). Revisiting the Causes and Meaning of Higher Education Massification in Sub-Saharan Africa: Evidence from Cameroon. Open Journal of Social Sciences, 9, 188-211. https://doi.org/10.4236/jss.2021.94015

Received: February 18, 2021

Accepted: April 18, 2021

Published: April 21, 2021

Copyright $\odot 2021$ by author(s) and Scientific Research Publishing Inc. This work is licensed under the Creative Commons Attribution International License (CC BY 4.0).

http://creativecommons.org/licenses/by/4.0/

\begin{abstract}
The lack of common agreement on the typology of causes/drivers of massification within the literature globally and the paradox between the meager GTER (Gross Tertiary Enrollment Ratio) and higher education massification in Sub-Saharan Africa require further reflection on this global issue (e.g., the massification of higher education). This study aimed therefore to investigate higher education massification in Cameroon, one of the Sub-Saharan African countries affected by this phenomenon. It employed a qualitative approach based on content analysis of secondary sources and semi-structured interviews with Cameroonian academic members, managers, and higher education officials to explore the causes and meaning of higher education massification in Cameroon. The findings highlighted three factors as major underlying drivers of higher education massification in Cameroon, namely: high rates of attendance and completion in secondary/high schools; open-door policy; and resource constraints. The study concludes that there is no exclusive relationship between the level of the GTER and higher education massification in Cameroon while referring to it as (a consequence of) the mismatch between student quantity-students number and resource quality and quantity. A call for action is made to policymakers to consider higher education massification and its potential effects on quality assurance as a critical concern by developing strategies to effectively address the problem of resource constraints among higher education institutions.
\end{abstract}

\section{Keywords}

Massification, Higher Education, Causes and Meaning, Sub-Saharan Africa, Cameroon 


\section{Introduction}

Cameroon is a Sub-Saharan African country of the Central African-Sub region. It is a former German colony (1884-1916) that was jointly ruled by France and Great Britain after the First World War, on a mandatory basis under the League of Nations, from 1919 to the 1960s. Modern higher education in Cameroon started after the country became an independent State in the 1960s. France was the main actor in the creation of the Cameroonian university by making available important resources (human, financial and physical resources) for the implementation of the project of higher education in the country. The French Foundation of Higher Education in Cameroon was the organ delegated by the French Ministry of National Education to build up the Cameroon higher education system in collaboration with the Cameroonian government (MINESUP, 2014). This means France was upstream and downstream in the process of designing and setting up the university institution in Cameroon (Bella, 2010). Indeed, articles 7 and 13 of the Cultural Cooperation Agreement between France and Cameroon, signed on 13 November 1960, states that "the French Government would assist in the creation, organization and development of a University in Cameroon to enable it to train locally the senior managers, it needed in the following fields: culture, teaching, research, and vocational training" (MINESUP, 2014). From independence in 1960 to the 1990s, the country's higher education system had only one public university, the University of Yaounde, previously known as the Federal University of Cameroon. During this period, the Cameroonian higher education landscape comprised the University of Yaounde (including three faculties, four schools, one specialized center, and two institutes) four University Centers with specific educational mandates created in 1977 in four different regions around the country. There was no private higher education institution by then and the education policy in place was an elitist policy based on the training of local officials (elites) capable of replacing Western expatriates holding administrative positions in the country before its independence (Njeuma et al., 1999). However, between the 1970s and 1980s, Cameroon higher education faced unprecedented challenges, with major ones being the exponential growth of student enrollments and retrenchment in public funding. Before the reform of 1993 for example, the country's only university, the University of Yaoundé, was experiencing exponential massive increases in student enrollments while its absorption capacity remained very limited (Njeuma et al., 1999; Ngwana, 2003). Attempts were made in the 1970s to monitor the fast-growing university student population by creating the University Centers of Dschang, Ngaoundere, Douala, and Buea. Yet, the problem of overcrowding in terms of tertiary student population persisted as student enrollments kept growing over the years. For instance student enrollments that were 17,535 over 1986, increased to 36,490 over 1990 and to 39,151 over 1991 , while the capacity to absorption remains insufficient to meet this demand (Njeuma et al., 1999). The great reform of 1993 of higher education in Cameroon intervenes therefore in 
response to this increasing massification of higher education. Indeed, student population rose from 17,535 in 1986 to 44,270 over 1992 . Thus, the University of Yaoundé had between 1991 and 1992 five times more students $(37,215)$ than its capacity of absorption (7000 students) (Njeuma et al., 1999; Michaela, 2012). However, even after the reform of 1993, Cameroonian higher education continued to suffer from unstoppable increases in student enrollments (Njeuma et al., 1999). The issue of massification in higher education is not peculiar to Cameroon alone, but it is common to all the regions of the world. The study stresses that no matter the current meager GTER in the Sub-Saharan African region (as compared to the GTER of the other regions of the world), higher education in Cameroon is paradoxically facing an unprecedented massification. The focus of this study is therefore to examine this phenomenon in the Sub-Saharan African region, with special attention paid to the case of Cameroon. The study intends to advance the debate on higher education massification by revisiting its causes and meaning from a Sub-Saharan African perspective, based on evidence from Cameroon.

\section{Literature Review}

The term mass higher education was first used in the USA (and, in particular, California) in the 1970s, referring to the growth of student enrollments in the postwar American higher education (Scott, Gallacher, \& Parry, 2016). In the 1970s, the American sociologist Martin Trow defined forms of higher education system by developing a tripartite typology of higher education systems, which allowed to measure and interpret the phenomenon of massification in higher education. Thus, national higher education systems that enrolled over 15 percent of secondary/high school leavers were defined as elite systems. Systems achieving an enrollment of between 15 percent and 50 percent were considered as mass systems, while those enrolling more than 50 percent were described as universal systems (Trow, 1973). According to Quintero-Re (2011), elite systems may be viewed as systems merely opened to privileged and talented groups, while mass systems are opened to those having the right and qualifications to enroll in higher education, and universal systems to all categories (Quintero-Re, 2011). Massification can thus be described as the mass adaptation of a phenomenon by the suppression of its distinguishing features (Mohamedbhai, 2008). Scott (1995) used the term massification in the context of higher education to describe "the rapid increase in student enrollment" in higher education institutions (Scott, 1995). Tlali et al. (2019), examining the implications of massification of education on quality assurance and assessment in higher institutions in Lesotho, defined it as massive and continuous enrollment of students into higher learning, while the capacity to absorb them remains insufficient to meet this demand (Tlali, Mukurunge, \& Bhila, 2019). Altbach (2010) described massification as "the most critical contemporary force pressing on universities" (Altbach, 2010). Thus, massification is a contemporary revolution in higher education (the shift 
from the elitist policy to the mass policy in higher education (Trow, 2000) which refers to massive enrollments of students in institutions of higher learning, with a mismatch between students enrollment and institutional absorbing capacity (Mohamedbhai, 2008; Tlali, Mukurunge, \& Bhila, 2019; Goolam, 2008). Concerning, the meaning of the concept of mass higher education, the literature has provided a two-dimensional meaning to it. Thus, the concept of massification of higher education is employed in a precise and a loose sense (Scott, 2017), the first sense (the precise sense) referring to the middle stage of Trow's three-level typology of higher education systems (Trow, 1973). The looser sense of the term mass higher education in turn refers to the global phenomenon of highly expanding student numbers within the universities and colleges since the 1960s (Scott, 2017). Kerr (2001) loosely referred to the concept and term of mass education in terms of "multiversity", emphasizing the institutional perspective. Kerr viewed mass higher education as a situation whereby a university with several constituent and affiliated institutions, such as separate campuses, colleges, and research centers (Kerr, 2001).

Massification is a major concern that higher learning institutions worldwide struggle to address, as it negatively affects quality assurance and assessment of learning, and teaching in concerned institutions (Tlali, Mukurunge, \& Bhila, 2019; Akoojee \& Nkomo, 2007; Tight, 2019). Mohamedbhai (2008) explored the effects of massification on African public higher education institutions, as well as possible strategies to address it, based on seven selected universities from seven African countries (e.g., Senegal, Mozambique, Ghana, Kenya, Burkina Faso, Kenya, and Zimbabwe). The study found that massification was caused by the need for African public higher education institutions to respond to historical conditions and to address equity-related issues through the democratization of higher education access. The democratization of higher education access being viewed as associated with social justice through resolving social and economic inequalities (Hornsby \& Osman, 2014). The study concluded that this phenomenon had negative consequences on higher education institutions in Africa. Such institutions experienced critical issues like inadequate staff-student ratio and inadequate physical infrastructure both affecting the quality of teaching, learning, and student assessment; graduate unemployment; inadequate student residences; and insufficient government funding (Mohamedbhai, 2008). Mohamedbhai conducted a similar study in 2014 and found that massification has had negative consequences on almost all of the public higher education institutions in Africa, including inadequate physical infrastructure, lack of adequate staffing, poor educational quality, graduate unemployment, and poor student mobility (Mohamedbhai, 2014). Exploring the experiences of academics and the challenges they faced in a large public university in Ethiopia during a period of graduate education expansion, Akalu (2016) also found that the onset of expansion, which results in mass higher education, merely leads to the decline of the quality of education (Akalu, 2016). Njeuma et al. (1999), describing the histori- 
cal mutations in Cameroon higher education found that Cameroonian higher education institutions have experienced the phenomenon of massification. They observe that the gradual increase in student population without expanding institutional infrastructures has resulted in a situation of overcrowded amphitheaters and saturated labs such that students are unable to carry out practical activities or tutorials, or to follow lectures in an atmosphere that is conducive to learning (Njeuma et al., 1999). Mve (2020) researched issues of talent cultivation in Cameroon higher education and found that massification was one of the main factors affecting higher education quality, which was an obstacle to effective talent cultivation in the country (Mve, 2020).

The effects of massification are likely to be experienced by higher education systems worldwide. Hornsby and Osman (2014) describing massification as a phenomenon that results in large class teaching in higher education, considered it as "a problem in promoting student learning, quality education, and consequently as a challenge to socio-economic development" since large class pedagogy generally correlates with low student performance (Hornsby \& Osman, 2014). Varghese (2015), exploring the massification of higher education in India, found that the challenges posed by massification are considerable in higher education institutions. Such challenges include "concerns for ensuring equity, improving quality, mobilizing funding, managing and regulating the system", which requires the role of the State to change "from financing and managing institutions to developing a framework for regulating the system to ensure equity in access and quality in outcomes" (Varghese, 2015). Mok and Jiang (2016), exploring issues related to the massification of Chinese higher education, observe that massification may affect the competitiveness of university graduates in the job market since it can lead to poor quality education and hence to educationjob mismatch (Mok \& Jiang, 2016). Trow (1962) searched on factors that could cause the massification of higher education and found that there were two main drivers of mass higher education systems. Trow's twin drivers generally included (a) the rising tide of social aspirations and expectations "generated by a higher level of high school graduation or secondary education completion and (b) the rapid economic evolution leading to the increasing demand for graduate-level jobs (Trow, 1962). Other linkages between access to higher education and "national liberation struggles" and "economic development" were emphasized in some world regions, specifically in Asia, Africa, the Middle East, and Latin America (Scott, 2017). However, the literature acknowledged that the scale of increase in tertiary enrollment "cannot be explained wholly, or even predominantly, in terms of workforce demand". As Trow (2000) and Scott (2017) supposed the dramatic growth of mass higher education has been driven by something more fundamental (Trow, 2000; Scott, 2017). Even "national liberation struggles" and "economic development" may not be appropriate drivers of higher education massification in all the indicated regions, currently.

In any event, the rationality of choosing this topic, i.e., the essence of this 
study lies in two significant observations drawn from the literature. 1) There is a lack of general agreement on the typology of causes/drivers of massification globally (the most common drivers reported in the literature including economic growth/development leading to increasing graduate-level jobs; social aspirations (triggering the desire to enroll in higher education) due to the increasing number of secondary/high school leavers; and liberation struggles). This involves revisiting the causes or drivers of higher education massification, especially in Sub-Saharan Africa as the focus of the study. 2) The GTER in Sub-Saharan Africa is particularly low as compared to that of the other regions of the world (Mohamedbhai, 2014; Scott, 2017). In 2018 for example, the GTER across the Sub-Saharan African region was 9 percent (and 14 percent in Cameroon) (World Bank, 2021a), which was still comfortably in the elite range (according to Trow's (1973) typology of higher education systems). However, higher education in Sub-Saharan African countries is paradoxically facing an unprecedented massification, with higher education institutions in the region continuously experiencing massive increases in student enrollments, well beyond their carrying capacity (Njeuma et al., 1999; Mohamedbhai, 2014; Mve, 2020). Thus, how can we explain this Sub-Saharan African Paradox? In other words, how can we explain the paradox between the meager GTER and higher education massification in Sub-Saharan Africa? This question involves a reflection on the meaning and understanding of higher education massification in Sub-Saharan Africa.

\section{Methodology}

This study adopted a qualitative approach and used interpretative analysis (Smith, 2004; Creswell, 2013). The study was based on content analysis of secondary sources (documentary evidence) (Polkinghorne, 2005; Bailey, 1994) and in-depth interviews with Cameroonian academic members and managers, as well as higher education officials (HEO) (Creswell, 2013). Both the content analysis and interviews were aimed at achieving an authentic narrative of the causes and meaning of massification in higher education (Yin, 2011; Creswell, 2013). The overarching research questions at the center of this study are concerned with the following: What are the causes of this massification of higher education? What does massification of higher education mean in Sub-Saharan Africa (e.g., Cameroon)?

\subsection{Recruitment and Sampling}

Participants in this study were selected using purposive sampling (Maxwell, 1996; Merriam \& Tisdell, 2015). The researcher employed a snowball sampling technique to identify study participants. Indeed, the researcher has been a student in one of the Cameroonian universities (e.g., the University of Yaounde 1) from 2008 to 2016 and was in contact with some faculty members and managers. Official approval was received from the Ministry of Higher Education (MOHE) in February 2019, before the study, which allowed the researcher to collect series 
of data in both State and private HEIs and the MOHE. The researcher relied on personal networks to identify and interview two initial study participants (Michael and Daniel) who referred him to other potential subjects (Taherdoost, 2016). Because members of the study's target population (especially, managers and HEO) were not easy to access, the use of the networks of initial participants was very important for recruiting additional participants (Breweton \& Millward, 2001). Formal (e-mails) and informal (WhatsApp) correspondence, as well as face-to-face meetings with potential interviewees, were used to invite participants to partake in the study.

Ten academics (four females and six males) partook in the study, including four faculty members, four academic managers, and two higher education officials (HEO). Participants' age range was between 40 and more than 50 . They belonged to a variety of disciplines, including STEM, humanities, health sciences, and social sciences. All participants (including academic managers and HEO) held a teaching position in at least one university, which was an important qualification to be capable of providing accurate descriptions of the phenomenon of higher education massification and related issues. Table 1 captures more details about participants' characteristics.

\subsection{Data Collection}

\subsubsection{Secondary Data}

The researcher conducted a content analysis to extract pieces of evidence from various secondary (documentary) sources on tertiary enrollments and issues associated with mass higher education. Some documents were provided by participants or by their colleagues (e.g., statistical yearbooks and (higher) education annual reports). Some other secondary data were retrieved from the different websites (e.g., the MOHE website, the World Bank website, and the UNESCO website). The researcher also consulted various work papers, published reports,

Table 1. Participants demographic profile.

\begin{tabular}{ccccc}
\hline Interviewees & Age range & Category & Discipline Area & Position \\
\hline Sarah & $40-49$ & Academic & Humanities & Department Head \\
John & $40-49$ & Academic & STEM & Division Head \\
Abigail & $40-49$ & Academic & Humanities & Faculty \\
Michael & $\geq 50$ & Academic & Health sciences & HEO \\
Mary & $30-39$ & Academic & Social sciences & Faculty \\
Daniel & $30-39$ & Academic & Social sciences & Faculty \\
Smith & $\geq 50$ & Academic & STEM & Faculty \\
Ana & $\geq 50$ & Academic & Humanities & Faculty Dean \\
Noah & $\geq 50$ & Academic & Humanities & Department Head \\
Richard & $\geq 50$ & Academic & STEM & HEO \\
\hline
\end{tabular}

${ }^{*}$ Pseudonyms are used for anonymity. 
and papers related to higher education and universities in Cameroon. The researcher collected significant information on student participation in secondary and higher education from such secondary sources, as well potential trends and issues associated with mass higher education. Table 2 presents a secondary data collection matrix for all documentary data explored in this study.

\subsubsection{Interviews}

To have a deep understanding of participants' experiences and perspectives on higher education massification, its drivers, and meaning, the researcher conducted semi-structured interviews with the 10 participants that were audio-recorded with participants' permission and lasted 45 to 60 minutes each. The inquirer conducted all interviews individually and did a verbatim transcription of each (Yin, 2011).

\subsection{Data Analysis}

The researcher began data analysis with open coding of the data sources (documentary and interview transcripts) to document higher education massification trends, drivers and meaning. This involved reading through interview transcripts and documentary sources and recording initial ideas on content and meanings of such data sources following Yin's (2011) steps, which allowed the identification of initial broad themes (Yin, 2011). The permanent examination was carried out on these respective themes to analyze their presence and prevalence within and across data sources (e.g., interview and secondary data) and to identify any convergence or divergence across the data and any connections between the verbal information (from interviews and documents) and statistical information from documentary sources (Strauss, 1987). Based on a line-by-line analysis, the recorded emergent themes were refined or clustered into specific overarching codes and sub-codes, while seeking both to reflect and understand (capture key features of) the views and perceptions of academics on mass higher education and related drivers and meaning (Creswell \& Poth, 2018; Saldana, 2016; Yin, 2011).

Table 2. Secondary data collection matrix-type of information by source.

\begin{tabular}{|c|c|}
\hline Information & Information Source \\
\hline Tertiary Enrollment-World Regions & $\begin{array}{c}\text { UNESCO Institute for Statistics World Bank } \\
\text { Reports }\end{array}$ \\
\hline Enrollment in Secondary Education-Cameroon & National Institute for Statistics-Report \\
\hline Higher Education Enrollment-Cameroon & $\begin{array}{c}\text { National Institute for Statistics-Report Statistical } \\
\text { Year Book of Higher Education }\end{array}$ \\
\hline $\begin{array}{l}\text { Higher Education Resources and } \\
\text { Funding-Cameroon }\end{array}$ & Statistical Year Book of Higher Education \\
\hline Trends and issues of Higher & Higher Education Reports \\
\hline Participation-Cameroon & Works on the Tertiary Sector \\
\hline
\end{tabular}




\section{Findings and Discussion}

\subsection{Causes of Higher Education Massification}

The findings revealed that the rapid and permanent growth of mass enrollments leading to the critical massification of higher education in Cameroon was caused or favored by three main factors. Such factors include the high rates of attendance and completion in secondary/high schools, the open-door academic policy adopted by the Cameroonian government for most institutions, and resource constraints within higher education institutions. The findings also support only the first point of Trow's (1962) view in terms of drivers of mass higher education, i.e., the social aspirations caused by higher rates of secondary/high school completion (Trow, 1962). Trow's second driver of massification of higher education, emphasized by Scott (2017) when explaining the phenomenon in African countries, was not supported by the results of this study. Indeed, economic growth/development was not found to be among the drivers of higher education massification in Cameroon, which appears not to be paradoxical. Considered as lower middle income (World Bank, 2021b), Cameroon has an economic growth level that may not cause an exceeded demand for graduate-level jobs capable of resulting in increased participation in higher education. Moreover, the findings revealed no linkage between higher education massification and "national liberation struggles", which was highlighted by Scott (2017) as a potential driver of mass higher education in regions such as Asia, Africa, the Middle East, and Latin America (Scott, 2017). There may still exist some neo-liberation movements in some parts of Africa, but these are not linked to the unprecedented increases in tertiary enrollments throughout the continent.

Large classes and crowded lecture rooms in our universities are due to the fact that so many students are passing the baccalaureate or the General Certificate of Education (GCE) each year and the doors of the university are opened to all of them (Ana).

This has no relationship with economic development. Our country's economic level is still very low and cannot justify the phenomenon of increased enrollments in higher education (Smith).

\subsubsection{Secondary/High School Attendance and Completion}

One of the main drivers of massification and increasing enrollments in Cameroon higher education is the highly increasing number of the population attending and completing secondary schools in the country (Njeuma et al., 1999). The exponential increase in the number of students attending secondary education is likely due to the freedom and compulsory policy implemented in the country's primary education sector. Indeed, since 2002, the Cameroonian government, the largest provider of education national wide, is implementing a free and compulsory primary education policy for public schools (Fonkeng, 2007; Djoyou Kamga, 2011).

Primary education is almost compulsory and available free to all. Thus, kids 
from all social classes are admitted to public primary schools without any discrimination. This, added to the policy of collective promotion that is implemented in our education system, naturally results in increasing numbers of students in secondary schools (Sarah).

The majority of students who complete their Baccalaureate or GCE advanced level are automatically enrolled in the university when they leave secondary school (Mary).

According to the data collected from the National Institute of Statistics (NIS), general secondary/high schools, for example, have made remarkable progress in terms of enrollments. Thus, the number of students attending the second cycle of general secondary education (comprising terminal grades) that was recorded between 2000 and 2001 was $67 \%$ higher than that recorded between 1990 and 1991. Secondary technical and vocational education experienced increases in student attendance during this period, as well (MINESEC, 2014; NIS, 2015). The high rates of attendance and completion in secondary schools have resulted in exponential growths of the school-going population in higher education institutions. Table 3 captures the evolution of the number of students completing secondary/high school and that of higher education enrollments over 2016-2018.

Table 3 shows that attendance rates keep increasing in secondary/high school, which likely has an impact on the higher education student population. Thus, the number of secondary/higher school leavers increased from 95,565 over 2016 to 101,487 over 2018 . These increases in secondary/high school completion have triggered the increase of higher education enrollments from 284,827 over 2016 to 323,672 over 2018 . This conceptualization of the direct impact of increases in secondary/high school completion on higher education enrollments has been acknowledged by the literature. Higher rates of secondary/high school completion would likely trigger massive enrollment of students into higher education (Tlali, Mukurunge, \& Bhila, 2019). Indeed, increasing growth in secondary/high school completion can only result in higher social demand for higher education in any region of the world (Trow, 1973; Scott, 2017; Mohamedbhai, 2008).

\subsubsection{Open-Door Policy}

At the beginning of higher education in Cameroon, the government has adopted an open-door academic policy. The open-door policy that aimed at making post-secondary education accessible to everyone was imposed on the majority of public universities, except the University of Buea, public professional and technical schools, and private institutions (Njeuma et al., 1999). So, the majority of

Table 3. Student population of terminal secondary school and higher education.

\begin{tabular}{cccc}
\hline Years & $\mathbf{2 0 1 6}$ & $\mathbf{2 0 1 7}$ & $\mathbf{2 0 1 8}$ \\
\hline Secondary School graduates & 95,565 & 92,524 & 101,487 \\
Higher Education Enrollments & 284,827 & 295,058 & 323,672 \\
\hline
\end{tabular}

Source: Ministry of Higher Education Report (MINESUP, 2020). 
public universities are obliged to enroll all students holding a high school diploma (e.g., the Baccalaureate or the GCE Advanced Level) (Fouda et al., 2012). This measure followed the United Nations requirements for education policy, whereby all citizens without exception, should have access to education at all levels (UNESCO, 2000).

We cannot do otherwise. All Cameroonians, like all other citizens in the world, have the right to education. This means that they should be offered wide access to education (Richard).

Following the government recommendation, we allow all those who have the qualifications to be enroll in university. There is not and there should not be any discrimination on that (Ana).

All applicants are generally admitted in the different majors based on their qualifications, no matter the number of candidates (Noah).

This supports the conclusion of Mohamedbhai (2014) that attempts to respond address issues associated with justice and equity have resulted in the widening of the university's gate, hereby triggering the massification of higher education (Mohamedbhai, 2014). This open-door policy was followed by a very generous system of student welfare which was put in place. For instance, before the reform of 1993 students paid no tuition fees, received subsidized accommodation and meals, and were also provided with well-paid bursaries. Even the tuition fee that the government established for public higher education institutions from the 1990s to date is still not high (Njeuma et al., 1999; Bella, 2010).

Almost all Cameroonian families can afford the school fee required in public universities. It is only XAF 50 thousand (Michael).

Like Secondary/high school education, the government equally subsidizes higher education, making many households able to afford it (John).

The open-door policy in Cameroon higher education has resulted in an extraordinary rampant massification, making universities to be severely and continuously over-crowded. For instance, tertiary enrollments increased from 77,707 over 2002 to 284,827 over 2018, while they have tripled between 2002 and $2014(357,504)$. Table 4 presents the details of the evolution of enrollments in higher education from 2002 to 2018.

The number of students in Cameroonian universities is likely continuing to increase over the years because of the tireless implementation of the open-door policy by higher education actors.

Admission to the first level of higher education is open to all candidates that completed secondary education. The race for placement into the available programs of study is keen as most qualified secondary school leavers are to be admitted to higher education institutions. Thus, it is normal that we face this situation of a plethora of students in our universities (Anna).

This conceptualization of the overcrowding situation in higher education 
Table 4. Enrollments in Cameroonian Universities: 2002-2018.

\begin{tabular}{cccc}
\hline Years & Public Sector & Private Sector & Total \\
\hline 2002 & 71,091 & 6616 & 77,707 \\
2004 & 81,240 & 6921 & 88,161 \\
2006 & 108,082 & 12,268 & 120,350 \\
2008 & 134,144 & 20,060 & 154,204 \\
2010 & 178,491 & 30,551 & 209,042 \\
2012 & 237,841 & 41,583 & 279,424 \\
2014 & 304,301 & 53,203 & 357,504 \\
2016 & 237,761 & 47,049 & 284,827 \\
2018 & 272,474 & 51,197 & 323,672 \\
\hline
\end{tabular}

Source: Yearbook of Higher Education, 2012, 2014, 2018 (MINESUP, 2012, 2014, 2018).

corroborates with the view of Quintero-Re (2011) that higher education massification always occurs when those who have the qualifications are all offered the right to enroll in the university (Quintero-Re, 2011). The open-door practice in Cameroon appears to be an approach used to ensure social justice through higher education democratization, i.e., by widening the gates of higher education institutions to welcome students of all social classes. There is thus a strong linkage between such policies and higher education massification (Mohamedbhai, 2014).

\subsubsection{Resource Constraints}

The limited financial capacity of higher education institutions has also been pointed out by the data as a major facilitator of the overcrowding situation experienced in the different campuses of higher education institutions in Cameroon. It was revealed that the open-door policy required an adequate increase of universities' resources to cope with this situation efficiently. Thus, more human and physical resources needed to be provided before the implementation of the open-door policy and this should become a continuous action as doors of higher education continue to be widely open to all secondary/high school leavers. However, such actions did not follow accordingly due to the lack of sufficient financial resources, which the provision of other resources depends on. Thus, the open-door policy has been adopted and continues to be implemented in an environment plagued by the crisis of financial, physical, and human resources.

The dramatic increase in student enrollments in higher education in Cameroon has not been matched with university funding effectively. The budget allocated to higher education is not enough to help all the universities deal with mass enrollments appropriately (Michael).

More faculty needed to be recruited and additional infrastructures to be built. Yet, the availability of public funds is limited such that these important actions did not follow effectively (John).

The government has even created new campuses, but both old and new 
campuses still lack adequate resources to manage all these students appropriately (Abigail).

The experience by Cameroonian higher education institutions of critical constraints in terms of financial, physical (infrastructural), and human resources in time of open-door policy is consistent with prior research that mass enrollment has been implemented worldwide with "no proportionate increase in human, financial, and physical support from public sources in the higher education sector" (Mohamedbhai, 2008). Indeed, enrollment in higher education has grown, expecting universities to accommodate greater numbers of students with fewer resources (Hornsby \& Osman, 2014). The overwhelming financial challenges facing the Cameroon higher education led to the crisis of physical and human resources. All concerns, i.e., the financial concern, physical resource concern, and human resource concern involve in one way or another the ongoing massification, be it at the level campuses or the level of classrooms, amphitheaters, and labs (Njeuma et al., 1999). According to the data, the public expenditure per student has declined considerably, and this has inevitably led to the deterioration of the learning environment. Though universities are encouraged to undertake incomes generating activities, their capacity to generate sufficient funds for their functioning is still critically weak (Ngwe, 2016). Consequently, the State continues to provide the bulk of the costs. However, the degree and constancy of such funding are very precarious as the universities compete for scarce funds with other sectors that the State also finances. Table 5 presents the details about the State expenditure concerning higher education from 2015 to 2018.

Table 5 shows that the public funding is unsubstantial, which may not help higher education institutions to monitor the increasing massive enrollments to avoid learning infrastructures to be overcrowded by building new or adequate ones, and to avoid critical teacher-student ratios by recruiting and motivating a sufficient number of teachers. For instance, only 1, 3 percent of the State budget was earmarked for higher education in 2018. Moreover, the data revealed that the budget allocated to higher education every budget year is likely to be showing a seesaw trend. Thus, the budget allocated to higher education in 2016 amounted to XAF 47. 6 billion against XAF 51. 9 billion over 2015. The same decrease in the timely budget allocated to higher education occurred in 2018 (XAF 61. 4 billion) as compared to the budget of 2017 (XAF 67. 6 billion). Apart from the State's financial support, Cameroonian institutions of higher education highly depend on school fees paid by students (Fouda et al., 2012). However, the

Table 5. Government funding for higher education.

\begin{tabular}{ccccc}
\hline Years & 2015 & 2016 & 2017 & 2018 \\
\hline $\begin{array}{c}\text { State Expenditure on Higher Education } \\
\text { (in CFA franc (XAF) billion) }\end{array}$ & 51,944 & 47,644 & 67,654 & 61,401 \\
$\begin{array}{c}\text { Percentage (\%) based on whole State Budget } \\
\text { (1, })\end{array}$ & 1,39 & 1,13 & 1,36 \\
\hline
\end{tabular}

Source: Ministry of Higher Education (MINESUP, 2020). 
school fee is not as considerable or high in public institutions as it is in private institutions. Njeuma et al. (1999) observed that:

In order not to render access to the university difficult to students from a low economic background, the Cameroonian government introduced a token registration fee of XAF 50 thousand per student per annum (approximately \$85) after the reform of 1993 . This fee is irrespective of the degree program or kind of degree pursued (Njeuma et al., 1999).

The data have posited the crisis of financial resources as the fundamental cause of other constraints faced by Cameroonian higher education institutions, including constraints associated with physical and human resources.

To build adequate lecture rooms and labs or recruit an adequate number of teachers requires funding. Thus, without sufficient financial resources, it is almost impossible to supply the university with adequate infrastructures and human resources to meet the current demand (Noah).

Universities should be encouraged to look for funds and to make money if the problems caused by massive enrollments are to be curbed (Richard).

Increasing enrollments due to the open-door policy in Cameroon higher education have not been followed by adequate actions as far as physical resources are concerned. Due to the widespread shortages of public funds and the limited capacity of institutions to generate sufficient funds by themselves, the physical resources in higher education institutions have not increased proportionately with these increased enrollments (Michaela, 2012; Bilola, 2015). For instance, the available lecture rooms and amphitheaters as well as labs, academic staff and administrative offices, and even sanitary facilities are grossly inadequate to meet the needs of the increasing student population in Cameroonian universities.

Lecture rooms are overcrowded as the size of these rooms is smaller than the number of students that should receive lectures there (Smith).

Sometimes, some students will be standing while we are having classes because there are not enough seats for everyone (Abigail).

Laboratory equipment is grossly insufficient for the number of students. This results in ineffectiveness in the teaching and learning process (Mary).

This supports the point of view of Njeuma et al. (1999) when describing the phenomenon of massification in Cameroon. They observe that it involves the gradual soaring of the student population, while the universities' infrastructures are not expanding accordingly. According to them, the gradual increase in student population without a proportionate expansion of institutional infrastructures results in numerous negative consequences such as overcrowded amphitheaters and saturated labs such that students are unable to carry out practical activities or tutorials, or to follow lectures in an atmosphere that is conducive to learning (Njeuma et al., 1999). Libraries are also concerned with this crisis. Most institutions have an acute shortage of books and periodicals. Some laboratory 
equipment is non-functional and has not been replaced. Students' residences are also insufficient to accommodate the total current number of students.

Quite apart from the fact that the main institutional library facility is inadequate for the number of students generally, faculties' libraries have been set in very narrow places that cannot absorb the number of students belonging to the concerned faculties. Besides, apart from the existence of so many outdated books in such libraries, the rate of acquisition of up-dated books is insufficient as per the demand for books (Sarah).

Thus, like numerous African countries, the rampant massification of higher education in Cameroon has resulted from the implementation of the open-door policy to admit most of the secondary/high school leavers in a context of inadequate and insufficient physical resources within higher education institutions (Mohamedbhai, 2008). Moreover, most institutions in Cameroon higher education have been unable to recruit additional academic staff to cope with the increased enrollment because of the shortage of funds (Mohamedbhai, 2014). The result has been that staff-student ratios have critically increased in many universities. For example, the teacher-student ratio has moved from 1/25 in 1962 to 1/54 over 1991 in Cameroon higher education. Moreover, this teacher-student ratio has been worsening in individual institutions. Table 6 below presents the difference between the teacher population and the student population in public universities from 2014 to 2018.

Although the teacher-student ratio has lightly decreased from 1/54 in 1991 to $1 / 48$ in 2014, it remains very high. Moreover, the teacher-student ratio is worse in the University of Douala (1/66.97) and the University of Yaounde $2(1 / 61.19)$ (MINESUP, 2020).

Faculty recruitment is far less than the growth in student enrollments. Thus, the staff-student ratio is high in Cameroonian higher education institutions, which renders teaching and supervision of student research very difficult (Daniel).

Therefore, the teaching load of faculty members has inevitably increased and this is complemented with increased administrative responsibilities. Indeed, the shortage of financial resources for the recruitment of a sufficient number of faculty members and the lack of adequate and sufficient physical resources to improve their working conditions have resulted in such professional concerns. Not

Table 6. Teacher-student population in public universities: 2014-2018.

\begin{tabular}{cccc}
\hline Years & 2014 & 2016 & 2018 \\
\hline Number of Students & 215,797 & 234,569 & 269,508 \\
Number of Teachers & 4462 & 4437 & 5175 \\
Teacher-Student Ratio & $1 / 48.36$ & $1 / 52.86$ & $1 / 52.07$ \\
\hline
\end{tabular}

Source: By the author based on data collected from the MOHE. 
surprisingly, academic staff is growing increasingly unhappy with their work conditions, particularly in campuses ravaged by a paucity of resources. This is consistent with the results of Akalu (2016) that faculty members would likely be subject to difficult working conditions mostly related to enhanced workload and resulted from the expansion of enrollments in a context of a shortage of resources (Akalu, 2016). This situation may affect higher education negatively, due to the numerous challenges it is capable of posing. The issues of inadequate physical resources and inadequate staffing or inadequate staff-student ratio due to insufficient funding can indeed result in low quality of teaching, learning and student assessment and supervision, graduate unemployment, inadequate student residences, and poor student mobility (Mohamedbhai, 2008, 2014). The ubiquity of higher education massification in an environment of a shortage of adequate resources may therefore affect quality assurance negatively, hereby leading to education-job mismatch (Njeuma et al., 1999; Varghese, 2015; Mok \& Jiang, 2016). This in turn can lead to graduate unemployment and the crisis of human capital, view as a necessity for the socio-economic development of the country (Hornsby \& Osman, 2014; Mve, 2020). Such a situation may indeed affect learning activities easily and result in critical low student performance (Hornsby \& Osman, 2014).

\subsection{What Higher Education Massification Means in Sub-Saharan Africa-Cameroon}

This section aimed to explain the paradox between the meager GTER recorded in the countries of Sub-Saharan Africa and the phenomenon of massification experienced within their higher education. The understanding of this paradoxical situation whereby lower GTER co-exists with massification allows capturing the meaning of higher education massification in Sub-Saharan Africa-Cameroon. The data showed that the phenomenon of massification is merely experienced at the level of institutional resources, especially physical and human resources, which highly depend on financial resources. The concept of massification in Cameroon higher education is likely linked to the concept of resource capacity or resource adequacy/quality. The data revealed that many Cameroonian higher education institutions are faced with the scarcity of adequate infrastructures and the shortage of academic staff in the context of the open-door policy, as the number of new and adequate classrooms, amphitheaters, and labs needed and the sufficient number of faculty members have not been provided since many years in many institutions. There is a strong linkage between the problem of lack of sufficient and adequate physical and human resources and the problem of shortage of funding within the Cameroonian university, which may certainly be the case of many countries in Sub-Saharan Africa.

We need more resources; we need more classrooms and more labs with a good absorption capacity. Our classrooms and labs are full of students because the space is small and the number of places is limited (Daniel). 
The recruitment of qualified teachers in a sufficient number is a necessity. The extant number of teachers is very low as compared to the number of students (Michael).

Recruitments are rare here. Even when the government launches campaigns of collective recruitments, some departments like mine will only receive one new teacher, while some will not receive a single teacher (Abigail).

The authorities used to explain that there are not enough financial resources to recruit a sufficient number of teachers or to provide all the needed infrastructures (Ana).

Meanwhile, the number of secondary/high school leavers continues to grow, though at a relatively slower pace than expected. Indeed, like in the whole of Sub-Saharan Africa, the gross tertiary enrollment ratio in Cameroon remains meager as compared to other countries. Mohamedbhai (2014) made the same observation by stating:

The tertiary education enrollment in African countries is unacceptably low and needs to be significantly increased to enable the maintenance of the continent's development trajectory (Mohamedbhai, 2014).

Table 7 presents the GTER (\%) of countries selected randomly from five regions with the lowest gross enrollment ratio for tertiary education based on the World Bank (2021a) data, namely: Latin America \& the Caribbean (Chile), South \& West Asia (Armenia), Arab States (Algeria), East Asia \& the Pacific (India), and Sub-Saharan Africa (Cameroon).

Table 7 shows that among countries with the lower GTER, Cameroon has the lowest higher education enrollment rates. According to Trow's (1962) tripartite typology of higher education systems, the countries of Sub-Saharan Africa (e.g., Cameroon) would be considered as having elitist systems rather than mass systems. However, the literature revealed in this respect that "a large proportion of Africa's "elite" pursue their studies outside Africa (or outside their native country)" (Mohamedbhai, 2014). Researchers in the area hold that Trow's interpretation of massification in the 1970s may no longer be appropriate now or the explanatory power of his original typology might have been eroded (Scott, P., 2017; Tight, M., 2019). Mohamedbhai (2014) argued that Trow’s typology “was relevant

Table 7. Gross tertiary enrollment ratio (GTER) (\%) selected countries.

\begin{tabular}{ccccccc}
\hline Countries GTER (\%) & $\mathbf{2 0 0 8}$ & $\mathbf{2 0 1 0}$ & $\mathbf{2 0 1 2}$ & $\mathbf{2 0 1 4}$ & $\mathbf{2 0 1 6}$ & $\mathbf{2 0 1 8}$ \\
\hline Algeria (Arab States) & -- & 29 & 32 & 34 & 42 & 51 \\
India (East Asia \& the Pacific) & 15 & 17 & 24 & 25 & 26 & 28 \\
Chile (Latin America \& the Caribbean) & 56 & 67 & 75 & 82 & 87 & 90 \\
Armenia (South \& West Asia) & 48 & 52 & 46 & 47 & 51 & 54 \\
Cameroon (Sub-Saharan Africa) & 7 & 11 & 13 & 16 & 12 & 14 \\
\hline
\end{tabular}

Source: World Bank-UIS data 2020. 
to countries which already had a well-established higher education system in the mid- $20^{\text {th }}$ century, such as the USA or Europe", but it was not "applicable to, for example, African nations" (Mohamedbhai, 2014).

Although the GTER in Cameroon was still the lowest among the selected countries, it has been increasing, even lightly, throughout the period from 2008 (7) to 2018 (14), which is due to the widely open access to tertiary education offered to all the students who complete and leave secondary education each year. Indeed, as seen earlier, the data have shown that most of secondary/high schools' leavers in the country are automatically admitted to the university within the framework of the open-door policy, whereas the resource capacity has not been extended accordingly in many higher education institutions. This is consistent with the results of Tlali et al. (2019) and Mohamedbhai (2014) that the massification observed in African higher education institutions is a result of continuous or open enrollments of students, while the resource capacity to absorb them remains insufficient or inadequate (Tlali, Mukurunge, \& Bhila, 2019; Mohamedbhai, 2014). The concept of mass higher education is thus more likely to be associated with resource capacity or/and resource adequacy in Cameroon higher education. The meaning of higher education massification in Cameroon and Sub-Saharan Africa as a whole does not just consist of an exclusive relationship between the GTER and Massification but mostly has to do with infrastructural capacity and adequacy, i.e., the institutional capacity to absorb all enrolled students. This does not corroborate the two-dimensional meaning given to massification of higher education by Trow (1973) and highlighted by Scott (2017). The first sense, the precise sense given to the concept of massification of higher education referring to the middle stage of Trow's three-level typology of higher education systems (Scott, 2017), cannot apply to a Sub-Saharan country like Cameroon because its GTER is not above and does not even reach 15 percent, which is required by Trow.

We may be tempted to associate Kerr's (2001) concept of 'multiversity' or Trow's looser sense for mass higher education to the meaning and understanding of higher education massification in Cameroon. However, the data have shown that Kerr's (2001) conceptualization of massification of higher education, as the situation whereby a university has several constituent and affiliated institutions, such as separate campuses, colleges, and research centers (Kerr, 2001), is not consistent with the Cameroonian experience. The phenomenon of massification experienced by higher education institutions in Cameroon merely refers to the accommodation of an exceeding number of students using inadequate quality and quantity of resources. Trow's loose sense in which mass higher education merely "denotes the general phenomenon of greatly expanding student numbers in universities and colleges after 1945 and especially after 1960" (Scott, 2017), aligns it with the contemporary expansion of welfare states and social markets. Scott (2017) revealed that this label (the loose sense of higher education massification) was grounded in political and cultural assumptions and carried 
ideological baggage (Scott, 2017). This makes the application of Trow's loose sense of mass higher education essentially problematic on a cross-regional basis. Indeed, political and cultural assumptions and even ideologies may vary from region to region, depending on the general context of each region. It may therefore be more convenient to contextualize the conceptualization or the understanding of higher education massification to achieve a reasonable or shared meaning/sense of it in regions like the region under study (e.g., the Sub-Saharan region). Thus, a contextual sense can be added to the other extant sense to optimize the conceptualization of higher education massification worldwide. Thus, the concept of mass higher education would be given a tri-dimensional meaning consisted of a precise sense, a loose sense, and a contextual sense. The contextual/context sense would posit the concept and term of higher education massification as depending on or relating to the circumstances that form the setting of it as a phenomenon. Concerning the Cameroonian case, the circumstances that form the setting of higher education massification include the continuous or open enrollments of students in higher education institutions in a context of a crisis of resources, i.e., while the resource capacity to absorb enrolled students remains insufficient or inadequate, leading to overcrowding of classrooms, amphitheaters, labs, etc. Therefore, higher education massification in Cameroon denotes a situation whereby there is an apparent mismatch between open and higher enrollments and resource adequacy and capacity, which causes the overcrowding of classrooms, amphitheaters, labs, etc... In other words, higher education massification refers to (the results of) the mismatch between student quantity and resource quality and quantity, which is the contextual sense of the concept, and the term. Thus, whenever there will be a mismatch between the implementation of the open-door policy and the resource quality and quantity in higher education in Cameroon, the involved higher education institutions will always experience the phenomenon of massification.

Figure 1 summarizes the findings of the study and stands as a potential

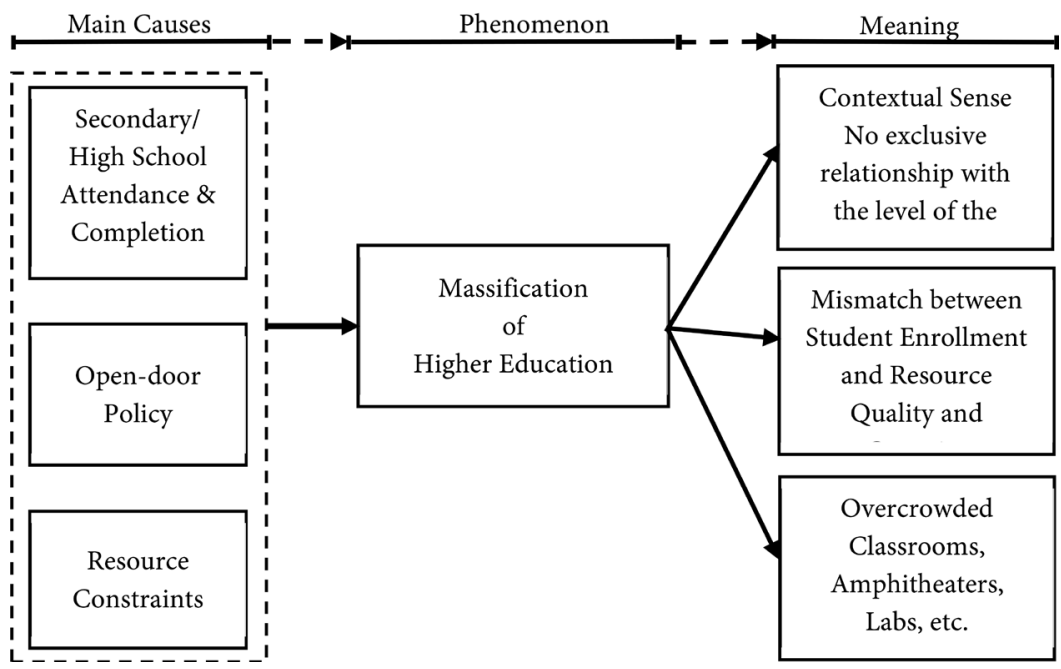

Figure 1. Causes and Meaning of Higher Education Massification in Cameroon. 
framework for the exploration of the causes and meaning of higher education massification in Africa, especially in Sub-Saharan Africa.

\section{Conclusion and Implications}

This study intended to advance the debate on higher education massification by revisiting its causes and meaning, especially in Sub-Saharan Africa, based on the Cameroonian experience. Time series data of students enrolled in higher education were also revisited from a global perspective to provide an overview of enrollments and highlights key developments for Sub-Saharan Africa (e.g., Cameroon) against the characteristics of other world regions. The data revealed that higher education institutions in Cameroon and Sub-Saharan Africa as a whole are experiencing continuously increasing enrollments, although the GTER in the region is still lower as compared to other regions. These increases in enrollments occur in a context of a crisis of resources, leading to the phenomenon of massification within higher education institutions. High rates of attendance and completion in secondary/high schools, open-door academic policy, and resource constraints were revealed as major drivers of mass higher education. Open enrollments of secondary/high school leavers were found to be encouraged and promoted among higher education institutions while there was no proportionate increase in their financial, physical, and human resources. The study found no exclusive relationship between the level of the GTER and higher education massification in Cameroon, and referred to it as (a result of) the mismatch between student quantity and resource quality and quantity within higher education institutions, manifested through overcrowded lecture rooms, labs, etc. The findings drawn from the study may not be directly generalizable to all countries in South-Saharan Africa but may serve as an important exploratory framework. In any case, challenges resulting from higher education massification in one African country are not dissimilar from those in other African countries (Mohamedbhai, 2014).

The findings of this study have implications for practice, policy, and further research in the area of higher education massification, including the following.

The phenomenon of higher education massification may not only be caused or driven by economic growth, social aspirations, and liberation struggles, as advocated by the literature. This phenomenon may also be triggered by the type of enrollment policy put in place in a higher education system and the practical conditions under which such enrollment policy is implemented. For example, major causes or drivers of massification of higher education in Cameroon include high rates of attendance and completion in secondary/high schools, opendoor policy, and resource constraints. Thus, to better control this phenomenon in the country, effective monitoring of the rates of secondary education attendance is required. As well, the policy of enrollment put in place should be well planned and designed along with plans for adequate resources availability (e.g., financial, physical, and human resources). 
A reconceptualization of higher education massification is put forward to optimize its sense and understanding in different regions of the world for its effective management and efficient monitoring of its potential effects on higher education quality. Indeed, the deeper understanding of the phenomenon of higher education massification does not exclusively depend on its relationship with the level of the GTER, as held by the literature on this area. To optimally investigate and understand this phenomenon in particular world regions, special attention should not be merely paid to a linkage with the GTER, but also to each region's contextual realities. For instance, in Cameroon and Sub-Saharan Africa as a whole, the concept of higher education massification refers to the outcome of the mismatch between student enrollments and the quality and quantity/capacity of resources available for effective and efficient absorption of enrolled students.

Higher education massification can affect education quality in Sub-Saharan countries like Cameroon, if not monitored efficiently. Therefore, policymakers and decision-makers should consider this critical issue by taking and planning appropriate and timely correctional measures, through the development of strategies intended to improve the financial capacity of higher education institutions, which may help to address other concerns associated with physical and human resources and ensure quality assurance among higher education institutions. Granting access to higher education to all citizens is of paramount importance, but this needs to be done along with appropriate measures that allow ensuring the availability of required qualitative and quantitative resources.

Further research may focus on 1) the meaning and understanding higher education massification may have in other particular world regions to enhance its optimal understanding globally; and 2) stages of the evolution of massification in higher education to better assess its origins, developments, and its trends in the past, present, and future. Subsequent studies may also pay attention to; 3) current overall consequences of higher education massification in Sub-Saharan Africa; and 4) current and future responses to this phenomenon in Sub-Saharan Africa, for its efficient monitoring and effective management of its consequences.

\section{Conflicts of Interest}

The author declares no conflicts of interest regarding the publication of this paper.

\section{References}

Akalu, G. A. (2016). Higher Education "Massification" and Challenges to the Professoriate: Do Academics' Conceptions of Quality Matter? Quality in Higher Education, 22, 260-276. https://doi.org/10.1080/13538322.2016.1266230

Akoojee, S., \& Nkomo, M. (2007). Access and Quality in South African Higher Education: The Twin Challenges of Transformation. South African Journal of Higher Education, 21, 385-399. https://doi.org/10.4314/sajhe.v21i3.25712 
Altbach, P. (2010). Access Means Inequality. International Higher Education, 61, 3-5.

Bailey, K. D. (1994). Methods of Social Research. Detroit, MI: Free Press.

Bella, A. E. (2010). L'Institution Universitaire au Cameroun: Dynamiques, Ruptures et Permanences d'une Réalité Plurielle; des Origines à 2001. Ph.D. Thesis, Yaounde: University of Yaounde I.

Bilola, T. S. D. (2015). Evaluating the Strategic Objectives of Cameroonian Higher Education: An Application of the Balanced Scorecard. Ph.D. Thesis, Turku: University of Turku-Finland.

Breweton, P., \& Millward, L. (2001). Organizational Research Methods. London: Sage. https://doi.org/10.4135/9781849209533

Creswell, J. W. (2013). Qualitative Inquiry and Research Design: Choosing among Five Approaches (3rd ed.). Thousand Oaks, CA: Sage.

Creswell, J. W., \& Poth, C. N. (2018). Qualitative Inquiry and Research Design: Choosing among Five Approaches (4th ed.). Thousand Oaks, CA: Sage.

Djoyou Kamga, S. A. (2011). Realizing the Right to Primary Education in Cameroon. African Human Rights Law Journal, 11, 171-193.

Fonkeng, G. E. (2007). The History of Education in Cameroon, 1844-2004. Lewiston, NY: Edwin Mellen Press.

Fouda, N. M. et al. (2012). Les Reformes de Gouvernance dans l'Enseignement Supérieur Camerounais. Réformes de Gouvernance dans l'Enseignement Supérieur: Quelles Politiques avec Quelles Effets (pp. 1-61). Dakar: UNESCO.

Goolam, M. (2008). The Effects of Massification on Higher Education in Africa. Washington DC: ADEA.

Hornsby, D. J., \& Osman, R. (2014). Massification in Higher Education: Large Classes and Student Learning. High Education, 67, 711-719.

https://doi.org/10.1007/s10734-014-9733-1

Kerr, C. (2001). The Uses of the University (5th ed.). Cambridge, Massachusetts: Harvard Uni-versity Press.

Maxwell, J. A. (1996). Qualitative Research Design: An Interactive Approach. London: Applied Social Research Methods Series.

Merriam, S. B., \& Tisdell, E. J. (2015). Qualitative Research: A Guide to Design and Implementation (4th ed.). Hoboken, NJ: Wiley.

Michaela, M. (2012). La Gouvernance dans l'Enseignement Supérieur: Quelles Politiques avec Quels effets? Étude des Réformes Conduites au: Burkina Faso, Cameroun, Maroc et Sénég et al. Paris: Institut International de la Planification de l’Education, UNESCO.

MINESEC (2014). Annuaire MINESEC 2012-2014. Yaoundé: Ministère des Enseignements secondaires.

MINESUP (2012). Annuaires Statistiques de l'Enseignement Supérieur 2003, 2004, 2005, 2006, 2007, 2008, 2009, 2011 et 2012. Yaoundé: MINESUP.

MINESUP (2014). L'Enseignement Supérieur au Cameroun: Cartographie 2014 des Institutions. Yaoundé: MINESUP.

MINESUP (2018). Yearbook of Higher Education. Yaounde: Ministry of Higher Education.

MINESUP (2020). Key Figures from of Higher Education in Cameroon. Yaounde: Ministry of Higher Education.

Mohamedbhai, G. (2008). The Effects of Massification on Higher Education in Africa. Accra: Association of African Universities. 
Mohamedbhai, G. (2014). Massification in Higher Education Institutions in Africa: Causes, Consequences, and Responses. International Journal of African Higher Education, 1, 59-83. https://doi.org/10.6017/ijahe.v1i1.5644

Mok, K. H., \& Jiang, J. (2016). Massification of Higher Education: Challenges for Admissions and Graduate Employment in China. London: Centre for Global Higher Education, UCL Institute of Education. https://doi.org/10.1007/978-981-10-1736-0 13

Mve, J. P. (2020). Promoting Innovative and Entrepreneurial Talent Cultivation in Cameroon Higher Education: Significance, Challenges and Opportunities. Journal of Education and Practice, 11, 42-53.

Ngwana, T. A. (2003). University Strategic Planning in Cameroon: What Lessons for SubSaharan Africa? Education Policy Analysis Archives, 11.

https://doi.org/10.14507/epaa.v11n47.2003

Ngwe, L. (2016). D’un Système Voué à la Construction de l'Etat au Projet d'un Modèle Entrepreneurial de Développement: La Métamorphose de l'Enseignement Supérieur au Cameroun. In D. L. E. Ngwe (Ed.), L'Enseignement Supérieur au Cameroun depuis la Réforme de 1993: Dynamiques et Perspectives (pp. 16-28). Dakar: CODESRIA.

NIS (2015). Annuaire Statistique du Cameroon. Yaoundé: Institut National de Statistiques.

Njeuma, D. L., Endeley, H. N., Mbuntum, F. F, Lyonga, N., Nkweteyim, D. L., Musenja, S. et al. (1999). Reforming a National System of Higher Education: The Case of Cameroon. Washington DC: ADEA Working Group on Higher Education, World Bank.

Polkinghorne, D. E. (2005). Language and Meaning: Data Collection in Qualitative Research. Journal of Counseling Psychology, 52, 137-145.

https://doi.org/10.1037/0022-0167.52.2.137

Quintero-Re, L. (2011). The Impact of Demand-Absorbing Universities in Mexico's Higher Education System. Reflecting Education, 7, 55-66.

Saldana, J. (2016). The Coding Manual for Qualitative Researchers (3rd ed.). London: Sage.

Scott, P. (1995). The Meanings of Mass Higher Education. Buckingham: SHRE and Open University Press.

Scott, P. (2017). Mass Higher Education. In Encyclopedia of International Higher Education Systems and Institutions (pp. 1-25). Dordrecht: Springer. https://doi.org/10.1007/978-94-017-9553-1 12-1

Scott, P., Gallacher, J., \& Parry, G. (2016). New Languages and Landscapes of Higher Education. Oxford: Oxford University Press. https://doi.org/10.1093/acprof:oso/9780198787082.001.0001

Smith, J. A. (2004). Reflecting on the Development of Interpretative Phenomenological Analysis and Its Contribution to Qualitative Research in Psychology. Qualitative Research in Psychology, 1, 39-54.

Strauss, A. L. (1987). Qualitative Analysis for Social Scientists. Cambridge: Cambridge University Press. https://doi.org/10.1017/CBO9780511557842

Taherdoost, H. (2016). Sampling Methods in Research Methodology; How to Choose a Sampling Technique for Research. International Journal of Academic Research in Management (IJARM), 5, 18-27. https://doi.org/10.2139/ssrn.3205035

Tight, M. (2019). Mass Higher Education and Massification. Higher Education Policy, 32, 93-108. https://doi.org/10.1057/s41307-017-0075-3

Tlali, N., Mukurunge, T., \& Bhila, T. (2019). Examining the Implications of Massification of Education on Quality Assurance and Assessment in Higher Institutions in Lesotho. International Journal of Trend in Scientific Research and Development (IJTSRD), 3, 1561-1568. https://doi.org/10.31142/ijtsrd23493 
Trow, M. (1962). The Democratization of Higher Education. European Journal of Sociology, 3, 231-262. https://doi.org/10.1017/S0003975600000618

Trow, M. (1973). Problems in the Transition from Elite to Mass Higher Education. Berkeley Cal: Carnegie Commission on Higher Education.

Trow, M. (2000). From Mass Higher Education to Universal Access. Minerva, 37, 303328. https://doi.org/10.1023/A:1004708520977

UNESCO (2000). Education for All. Paris: UNESCO.

Varghese, N. V. (2015). Challenges of Massification of Higher Education in India (pp. 147). CPRHE Research Papers, 1.

World Bank (2021a). School Enrollment, Tertiary (\% Gross)_UNESCO Institute for Statistics: Data as of September 2020. Washington DC: World Bank Group. https://data.worldbank.org/indicator/SE.TER.ENRR

World Bank (2021b). Population Estimates and Projections. Washington DC: World Bank Group.

https://databank.worldbank.org/source/health-nutrition-and-population-statistics:-pop ulation-estimates-and-projections

Yin, R. K. (2011). Qualitative Research from Start to Finish. New York: The Guilford Press. 